\section{B. Hofmann svarer:}

Feilslutninger blir ikke riktige av å gjentas mange ganger. I et forsøk på å presisere sin kommentar argumenterer Gunhild Garmo Hov og medarbeidere for at NIPT vil gi «bare fem falskt positive resultater» per 1000 kvinner, til forskjell fra 100-149 ved KUBtest ved en prevalens på $0,5 \%$. «Antall sant positive resultater blir ca. 5 i begge tilfeller.» Det svarer til en positiv prediktiv verdi på rundt $50 \%$.

Det er vanskelig å forstå at Hov og medarbeidere har lest artikkelen de refererer til. Poenget er at de prediktive verdiene for den aktuelle målgruppen er ukjent. Forfatterne av den refererte artikkelen konkluderer med at «Without additional evidence, however, the clinical utility of cfDNA remains uncertain. (...) For now, as with many medical innovations, it will fall to physicians to hold the line against pressures promoting diffusion of cfDNA testing beyond the boundaries of available evidence» (1).

Hovedpoenget er at vi fortsatt ikke har dokumentert kunnskap fra de aktuelle gruppene. Hov og medarbeidere forutsetter fortsatt det som skal vises, og de forutsetter at hensikten med testen er god. Mitt poeng er at vi trenger kunnskap om det første og argumenter for det siste. Jeg skulle ønske at Hov og medarbeidere kunne bidra med argumenter, om ikke med kunnskap.

\section{Bjørn Hofmann}

b.m.hofmann@medisin.uio.no

Bjørn M. Hofmann (f. 1964) er professor i medisinsk etikk ved Høgskolen i Gjøvik og ved Universitetet i Oslo. Han forsker og underviser i medisinsk filosofi, vitenskapsteori og etikk.

Ingen oppgitte interessekonflikter.

\section{Litteratur}

1. Morain S, Greene MF, Mello MM. A new era in noninvasive prenatal testing. N Engl J Med 2013; 369: 499-501.

Dette er en redigert versjon av debatten, publisert på nett 23.12. 2013. http://tidsskriftet.no/article/3103954/

\section{Bedre spesifisitet \\ gir mindre skade av friske fostre}

Morain og medarbeidere skriver i sin artikkel om DNA-basert testing (cfDNA) (1): «It has a sensitivity exceeding $98 \%$ and a specificity above $99.5 \%$.» Dette er også bekreftet i populasjoner som likner på vår (2). Dagens KUB-test kan ikke måle seg med en slik spesifisitet, uten å gå på bekostning av sensitiviteten. De skriver også: «Although sensitivity and specificity are unaffected by the condition's prevalence in the test population, PPV and negative predictive value (NPV) vary considerably with prevalence.»

Selvsagt varierer de prediktive verdiene med prevalensen! Men hvis man bytter ut dagens KUB-test med DNA-basert testing for akkurat de samme kvinner som i dag får tilbud om KUB-test, dvs. holder prevalensen uendret, oppnår man et lavere antall falskt positive prøvesvar gitt samme antall sant positive prøvesvar. Det betyr et lavere antall invasive tester og mindre skade på friske fostre.

Sitatet «For now, as with many medical innovations, it will fall to physicians to hold the line against pressures promoting diffusion of cfDNA testing beyond the boundaries of available evidence» er skrevet i bekymring over den hurtige spredningen av kommersielt basert cfDNA-testing i USA som er tilgjengelig for den generelle befolkning, med de reguleringer som gjelder for helsevesenet $i$ det samfunnet, og har ingen relevans for diskusjonen om antall falskt positive prøveresultater ved bruk på den høyrisikopopulasjonen som i dag får tilbud om KUB-test i Norge. Det er det vi har uttalt oss om.
Gunhild Garmo Hov (f. 1978) er overlege ved Avdeling for medisinsk biokjemi, St. Olavs hospital.

Oppgitte interessekonflikter: Hun er ansatt ved avdelingen som analyserer blodprøvene til KUB-test i Norge.

Arne Åsberg (f. 1951) er overlege ved Avdeling for medisinsk biokjemi, St. Olavs hospital.

Oppgitte interessekonflikter: Han er ansatt ved avdelingen som analyserer blodprøvene til KUB-test i Norge.

Ketil Thorstensen (f. 1957) er ph.d., sivilingeniør og biokjemiker ved Avdeling for medisinsk biokjemi, St. Olavs hospital.

Oppgitte interessekonflikter: Han er ansatt ved avdelingen som analyserer blodprøvene til KUB-test i Norge.

Litteratur

1. Morain S, Greene MF, Mello MM. A new era in noninvasive prenatal testing N Engl J Med 2013; 369: 499-501.

2. Gil MM, Quezada MS, Bregant B et al. Implementation of maternal blood cellfree DNA testing in early screening for aneuploidies. Ultrasound Obstet Gynecol 2013; 42: 34-40.

Dette er en redigert versjon av debatten, publisert på nett 7.1. 2014. http://tidsskriftet.no/article/3103954/

\section{B. Hofmann svarer:}

Det står åpenbart mye på spill for Gunhild Garmo Hov og medarbeidere. Det er viktig for dem å få frem at det å erstatte KUBtesten med NIPT, vil gjøre testingen for trisomi 21, 18, og 13 bedre. Derfor gjentar de det for tredje gang - nå med referanse til en nyere studie (1).

Grunnen til at de heller ikke denne gangen lykkes, er at studien som de viser til, forutsetter bruk av ultralyd og serumtester sammen med NIPT, altså ikke som erstatning for disse. Faktisk fordrer fremgangsmåten at det gjøres en ekstra ultralydundersøkelse ved ti uker for å ekskludere flerlingsvangerskap. Studien er altså på ingen måte sammenliknbar med det man ønsker å bruke testen til i Norge. Heller ikke denne studien presenterer prediktive verdier, slik som etterlyst $(2,3)$. Den dokumenterer ikke engang sensitiviteten. Vi må være varsomme med å bruke mangelfulle enkeltstudier i prinsipielle debatter.

Jeg vil benytte anledningen til å takke Hov og medarbeidere for en interessant debatt. Den viser med all tydelighet behovet for en grundig og kompetent gjennomgang av faktagrunnlaget - i tillegg til de etiske aspektene, som jeg etterlyste i min leder.

\section{Bjørn Hofmann}

b.m.hofmann@medisin.uio.no

Bjørn M. Hofmann (f. 1964) er professor i medisinsk etikk ved Høgskolen i Gjøvik og ved Universitetet i Oslo. Han forsker og underviser i medisinsk filosofi, vitenskapsteori og etikk.

Ingen oppgitte interessekonflikter.

Litteratur

1. Gil MM, Quezada MS, Bregant B et al. Implementation of maternal blood cellfree DNA testing in early screening for aneuploidies. Ultrasound Obstet Gynecol 2013: 42: 34-40.

2. Morain S, Greene MF, Mello MM. A new era in noninvasive prenatal testing N Engl J Med 2013; 369: 499-501.

3. Hofmann B. Forbedret fosterdiagnostikk? Tidsskr Nor Legeforen 2013; 133 : 2336.

Dette er en redigert versjon av debatten, publisert på nett 8.1.2014. http://tidsskriftet.no/article/3103954/ 